JAMP: Jurnal Adminitrasi dan Manajemen Pendidikan Volume 1 Nomor 3 September 2018, Hal : 255-262

Tersedia Online di http://journal2.um.ac.id/index.php/jamp/ ISSN 2615-8574 (online)

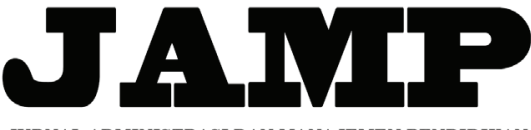

JURNAL ADMINISTRASI DAN MANAJEMEN PENDIDIKAN

\title{
STUDI KASUS IMPLEMENTASI PENDIDIKAN KARAKTER PADA SEKOLAH DOLAN
}

\author{
Febrina Evananda \\ Ibrahim Bafadal \\ Ahmad Yusuf Sobri
}

E-mail: febrinaevananda1@gmail.com

Universitas Negeri Malang, Jalan Semarang No.5 Malang

\begin{abstract}
The purpose of this study is to describe the parties involved in the implementation of character education; strategy of applying character values; supporting factors in the implementation of character education in; obstacles in the implementation of character education; and the form of supervision of character education in School of Dolan Vila Bukit Tidar Malang. The approach used in this research is qualitative approach and data collection using interview, observation and documentation technique and analyzed qualitatively descriptive. The research findings show that the application of character values in the implementation of character education at Dolan School is applied through teaching and learning process, school culture and habituation.
\end{abstract}

Keywords : implementation, character education, dolan school

\begin{abstract}
Abstrak : Tujuan penelitian ini untuk mendeskripsikan pihak-pihak yang terlibat dalam implementasi pendidikan karakter; strategi penerapan nilai-nilai karakter; faktor pendukung dalam pelaksanaan pendidikan karakter di; faktor penghambat dalam pelaksanaan pendidikan karakter; dan bentuk pengawasan pendidikan karakter di Sekolah Dolan Vila Bukit Tidar Malang. Pendekatan yang diguanakan dalam penelitian ini adalah pendekatan kualitatif serta pengumpulan data menggunakan teknik wawancara, observasi dan dokumentasi dan dianalisis secara kualitatif deskriptif. Temuan penelitian menunjukkan penerapan nilai-nilai karakter dalam pelaksanaan pendidikan karakter di Sekolah Dolan diterapkan melalui proses belajar mengajar, budaya yang ada di sekolah serta pembiasaan.
\end{abstract}

Kata kunci: implementasi, pendidikan karakter, sekolah dolan

Banyak aspek yang dijadikan tolok ukur untuk meningkatkan kualitas pendidikan aspek tersebut antara lain proses belajar mengajar di sekolah, lengkapnya sarana dan prasarana, keprofesionalan tenaga pendidik di sekolah, dan output peserta didiknya. Output peserta didik yang berkualitas dapat dilihat dari tingkat pemahaman dan hasil yang diperoleh dalam bidang akademik maupun nonakademik (Sutama dan Rahayu, 2015). Pendidikan karakter yang tertanam dengan baik pada peserta didik pada lembaga pendidikan dapat menghasilkan output yang baik. Sekolah harus mengupayakan terbentuknya nilainilai karakter dalam meningkatkan kualitas sekolah (Sobri, 2010). Dengan diterapkannya pendidikan karakter diharapkan dapat menyukseskan pendidikan di Indonesia.

Pendidikan karakter dijadikan suatu penguat dalam pewujudan tujuan pendidikan nasional yaitu agar peserta didik dapat secara aktif mengembangkan potensi untuk memiliki kekuatan kepribadian, spiritual keagamaan, pengendalian diri, akhlak yang mulia, kecerdasan, dan ketrampilan yang diperlukan dirinya, masyarakat, bangsa dan Negara. Pendidikan karakter diharapkan dapat menyukseskan pendidikan di 
Indonesia. Karena karakter memiliki fungsi penguat bangsa. Karakter merupakan kespontanan manusia dalam bertindak dan bersikap, yang telah melekat dalam diri individu sehingga ketika muncul tidak perlu dipikirkan lagi Imam Ghozali (dalam Muslich, 2011: 70).

Salah satu faktor pendorong orangtua menyekolahkan anaknya di lembaga nonformal karena ingin mengawasi anaknya. Dengan adanya homeschooling atau lembaga nonformal maka dapat memberikan kebebasan waktu bagi orang tua untuk dapat mengawasi anak mereka, karena kegiatan pembelajaran dapat dilakukan di rumah atau sesuai dengan tempat dan waktu yang tentukan sehingga orang tua bisa mengawasi anak. Pendidikan karakter tidak hanya dapat diterapkan melalui proses pembelajaran di kelas, pendidikan karakter bisa diterapkan melalui kultur sekolah dalam lembaga pendidikan tersebut. Bafadal (2016: 5) berpendapat bahwa "budaya pembelajaran yang harus diciptakan oleh kepala sekolah meliputi pembelajaran kokurikuler, intrakurikuler, dan ekstrakurikuler, serta nonkurikuler dalam rangka menumbuhkan budi pekerti yang baik pada siswa".

Langkah awal penerapan pendidikan karakter adalah dengan menanamkan kesadaran bersama dan menyamakan persepsi akan pentingnya pengintegrasian nilai-nilai karakter yang ada pada semua aktivitas sehingga nilai tersebut bisa menjadi kebiasaan oleh semua stakeholder (Salim, 2015). Pendidikan karakter adalah satu kewajiban karena pendidikan tidak hanya mengharuskan peserta didik menjadi cerdas akademik saja melainkan suatu pendidikan mengharuskan peserta didik mempunyai etika yang baik, sikap santun dan menghargai agar keberadaan peserta didik di masyarakat dapat bermakna dalam keberagaman kehidupan di masyarakat.

Nilai-nilai yang perlu dikembangkan pada diri peserta didik adalah kejujuran, religi, disiplin, toleransi, mandiri, kerja keras, kreatif, rasa ingin tahu, demokratis, cinta tanah air, semangat kebangsaan, menghargai prestasi, bersahabat/komunikatif, gemar membaca, cinta damai, peduli sosial, peduli lingkungan, dan tanggung jawab (Kemdiknas, 2010). Penanaman nilai-nilai karakter tersebut dapat diintegrasikan melalui proses pembelajaran di kelas ataupun dengan kegiatan pembiasaan. Kegiatan pembiasaan merupakan tindakan yang dilakukan secara terus-menerus dalam kegiatan sehari-hari individu maka akan terbentuk karakter individu tersebut (Gunawan, 2012).

Nilai-nilai karakter dapat diintregasikan dalam kegiatan belajar mengajar, selain itu pendidikan karakter dapat dikembangakan ke dalam program sekolah dalam pendidikan karakter siswa di sekolah yaitu berupa pembiasaan-pembiasaan baik berupa kegiatan keagaman maupun kegiatan yang bercorak umum (Marzuki, 2015). Nilai-nilai karakter harus dapat diinternalisasikan kepada seluruh siswa. Pendidikan karakter tidak hanya sekedar dibacakan dan dihafal tetapi harus benar-benar terealisasikan dalam kehidupan sehari-hari baik di sekolah, di rumah maupun di luar masyarakat.

Implementasi pendidikan karakter di sekolah akan berjalan dengan efektif apabila penerapan pendidikan karakter di lembaga pendidikan dimulai sejak sekolah dasar. Kegiatan pembelajaran yang dilakukan dalam proses peningkatan pendidikan budaya dan karakter bangsa yaitu dengan mengupayakan peserta didik memahami dan mengakui nilai-nilai budaya dan karakter bangsa sebagai milik mereka dan bertanggung jawab atas hasil keputusan yang diambilnya dengan tahap mengenal pilihan hingga menentukan pendirian, kemudian mewujudkan suatu nilai sesuai dengan keyakinan pada diri siswa (Wibowo, 2012).

\section{METODE}

Pendekatan dalam penelitian ini adalah kualitatif karena ingin mengetahui fenomena yang dialami oleh subjek penelitian (Moleong, 2010). Penelitian ini menggunakan rancangan studi kasus. Teknik yang digunakan dalam pengumpulan data adalah wawancara, observasi, dan dokumentasi. Peneliti berkedudukan sebagai instrumen kunci sebagai pengumpul data dan mengetahui keadaan lapangan untuk memperoleh data secara mendalam dan menyeluruh. Lokasi penelitian ini dilaksanakan di Sekolah Dolan Vila Bukit Tidar Malang.

Data yang dikumpulkan dalam penelitian ini yaitu data yang berhubungan dengan pihak-pihak yang terlibat dalam implementasi pendidikan karakter, strategi penerapan nilai-nilai karakter pada 
peserta didik, faktor pendukung dalam implementasi pendidikan karakter, faktor penghambat dalam implementasi pendidikan karakter, dan bentuk pengawasan pendidikan karakter. Sumber data dalam penelitian ini yaitu diperoleh melalui wawancara kepada informan yaitu tutor, kepala sekolah, dan orang tua siswa. Wawancara yang dilakukan peneliti adalah wawancara mendalam dan terstruktur. Sumber data lain dalam penelitian berupa dokumen-dokumen terkait dengan pendidikan karakter. Analisis data dilakukan menggunakan reduksi data, penyajian data dan penarikan kesimpulan (Ulfatin, 2015).

\section{HASIL}

\section{Pihak-pihak yang Berperan dalam Implementasi Pendidikan Karakter di Sekolah Dolan Vila Bukit Tidar Malang}

Implementasi pendidikan karakter di Sekolah Dolan melibatkan kepala sekolah, tutor dan orang tua siswa. Peran kepala sekolah dalam jalannya pendidikan karakter yaitu: (1) mendukung keberhasilan pendidikan karakter di sekolah; (2) menyiapkan waktu tertentu untuk melakukan kegiatan evaluasi atau koordinasi terhadap jalannya pendidikan karakter; (3) mengadakan fasilitas-fasilitas perlengkapan kerja yang dibutuhkan untuk menyusun kinerja yang efisien; (4) selain itu kepala sekolah terlibat langsung untuk menanamkan nilai-nilai karakter pada diri siswa di sela-sela kegiatan kepala sekolah.

Peran tutor dalam implementasi pendidikan karakter di Sekolah Dolan yaitu: (1) sebagai sumber belajar peserta didik dan berpartisipasi langsung dalam proses pembelajaran, yaitu dengan melaksanakan interaksi langsung dengan peserta didik dalam mendiskusikan materi pembelajaran; (2) guru berperan sebagai contoh tauladan peserta didik; (3) sebagai motivator siswa agar siswa selalu semangat dalam belajar, sebagai pendidik guru di Sekolah Dolan juga menunjukkan sikap-sikap yang terpuji dan selalu memberi contoh panutan untuk peserta didik.

Tutor, kepala sekolah, dan orangtua sangat berperan dalam jalannya pendidikan karakter di Sekolah Dolan ini. Peran orang tua dalam jalannya pendidikan karakter di Sekolah Dolan yaitu: (1) menenmpatkan tugas dan kewajiban sebagai orangtua; (2) selalu memberikan motivasi-motivasi kepada anak; (3) menenmpatkan tugas dan kewajiban sebagai orangtua; (4) selalu memberikan motivasimotivasi kepada anak; (5) menyiapkan diri menjadi model atau panutanyang baik; dan (6) berperan serta dalam belajar anak.

\section{Strategi Penerapan nilai-nilai Karakter di Sekolah Dolan Vila Bukit Tidar Malang}

Karakter mempunyai nilai-nilai yang harus dikembangkan pada diri peserta didik di suatu lembaga pendidikan agar tujuan pendidikan dapat berjalan sebagaimana yang diharapkan. Lembaga pendidikan merupakan salah satu lembaga yang efektif dalam penerapan nilai-nilai karakter pada diri peserta didik agar dapat menjalankan perannya sebagai individu yang berguna. Sekolah Dolan menerapkan berbagai nilai karakter. Stategi yang dilakukan Sekolah Dolan dalam menerapkan nilai-nilai karakter yaitu melalui proses belajar mengajar dan melalui budaya yang ada di sekolah. Penerapan nilai-nilai karakter selalu dilakukan dalam aktivitas sehari-hari di sekolah, hal tersebut dikarenakan pendidikan karakter harus dilakukan secara berkelanjutan agar nilai-nilai karakter lebih menyatu pada diri peserta didik.

Strategi penerapan nilai-nilai karakter di Sekolah Dolan diberikan melalui pengintegrasian nilai-nilai karakter pada proses belajar mengajar berlangsung di dalam dan di luar kelas, dimana dalam kegiatan pembelajaran tutor selalu menanamkan sikap saling menghormati dalam perbedaan, dan memulai serta mengakhiri kegiatan belajar mengajar dengan kepercayaan masing-masing, mendorong siswa untuk menentukan agenda tujuan pembelajaran hari itu secara bersama-sama, pada proses belajar mengajar guru selalu mencantumkan nasehat-nasehat kepada siswa yang berisi nasehat moral.

Penerapan nilai-nilai karakter di Sekolah Dolan melalui budaya sekolah yaitu melalui kegiatan: (1) kegiatan spontan, dilakukan tanpa direncanakan, kegiatan spontan yang dilaksanakan di Sekolah Dolan adalah saling membantu ketikan ada yang membutuhkan, membuang sampah pada tempatnya. (2) kegiatan yang rutin dilakukan di Sekolah Dolan Vila Bukit Tidar Malang yaitu melaksanakan nilai-nilai ajaran agama yaitu dengan sholat dhuhur berjamaah, budaya salim dengan tutor atau orang tua, selalu 
menjaga lingkungan dan menjaga kebersihan, mengucapkan salam jika bertemu, selalu berdoa sebelum memulai pelajaran. (3) kegiatan keteladanan, di Sekolah Dolan juga menerapkan kegiatan peneladanan yang dilakukan oleh tutor dan seluruh warga sekolah. Sebagai pendidik tutor harus memberikan contoh teladan kepada peserta didik.Sebelum menerapkan kepada siswa di Sekolah Dolan, tutor dan kepala sekolah tentunya harus memberikan contoh terlebih dahulu dan mempraktikkan dengan sesama tutor. Dengan tutor dapat mempraktikkan siswa dapat mengetahui dan mencontohnya. (4) pengkondisian, merupakan kegiatan penataan kondisi yang dapat mendukung jalannya pendidikan karakter. Pendidikan karakter di Sekolah Dolan Vila Bukit Tidar Malang juga menempel poster-poster di area sekolah sebagai cara sekolah menciptakan kondsi yang mendukung terlaksananya pendidikan karakter. Sekolah Dolan sering mengadakan kegiatan outdor yaitu berupa outbond. Tujuan kegiatan outbond memiliki manfaat diantara adalah untuk melatih anak supaya lebih terampil, berpengalaman dan bertujuan untuk memberikan wawasan tambahan pada diri siswa.

\section{Faktor Pendukung dalam Implementasi Pendidikan Karakter di Sekolah Dolan Vila Bukit Tidar Malang}

Pelaksanaan pendidikan karakter tentunya tidak terlepas dari adanya faktor pendukung. Berdasarkan temuan penelitian di Sekolah Dolan Vila Bukit Tidar Malang terdapat faktor pendukung dalam implementasi pendidikan karakter. Faktor pendukung yang ada di Sekolah Dolan berdasarkan hasil penelitian adalah: (1) adanya kesadaran dan komitmen yang kuat dari orangtua, tutor, kepala sekolah demi mendidik peserta didik agar berkepribadian yang baik; (2) selalu melakukan kerjasama dengan tutor dan orang tua peserta didik dalam melaksanakan pendidikan karakter untuk siswa; (3) rutin mengadakan rapat koordinasi tiap satu bulan sekali bersama guru-guru yang bertujuan untuk saling berkomunikasi dan dapat memecahkan masalah secara bersama jika menemukan masalah yang dihadapi khususnya dalam pendidikan siswa; (4) adanya fasilitas-fasilitas pendukung implementasipendidikan karakter di sekolah.

\section{Faktor Penghambat dalam Implementasi Pendidikan Karakter di Sekolah Dolan Vila Bukit Tidar Malang}

Faktor penghambat dari implementasi pendidikan karakter di Sekolah Dolan adalah kurangnya kesadaran dari peserta didik untuk melaksanakan nilai-nilai karakter, selain itu keanekaragaman karakteristik peserta didik membuat tutor sulit untuk mengkondisikan. Solusi untuk menangani faktor penghambat tersebut yaitu dengan rutin melakukan rapat koordinasi dengan tutor dan orang tua peserta didik.

\section{Bentuk Pengawasan Pendidikan Karakter di Sekolah Dolan Vila Bukit Tidar Malang}

Pengawasan adalah proses pemantauan dan penilaian atas tercapainya tujuan yang telah ditetapkan, pengawasan merupakan suatu cara yang dilakukan oleh suatu lembaga dalam mewujudkan kinerja dan mutu yang efektif dan efisien. Bentuk pengawasan yang dilakukan oleh Sekolah Dolan dalam implementasi pendidikan karakter adalah: (1) pengawasan melibatkan seluruh pihak sekolah dolan; (2) pengawasan secara langsung pada peserta didik melalui pembiasaan-pembiasaan yang dilaksanakan peserta didik selama peserta didik berada di lingkungan sekolah; (3) pengawasan melalui jurnal harian peserta didik; (4) pengawasan melalui hasil raport peserta didik; dan (5) pengawasan melalui rapat evaluasi dan koordinasi untuk guru.

Semua kegiatan yang dilakukan di Sekolah Dolan harus dievaluasi agar dapat dilihat ketercapaian kegiatan yang telah dilaksanakan oleh sekolah. Kegiatan evaluasi dilakukan pada saat rapat evaluasi dan koordinasi antara kepala sekolah dan guru. Kegiatan rapat evaluasi dan rapat evaluasi ini menjadi kegiatan rutin bagi sekolah untuk menilai pekerjaan yang telah dilaksanakan. Kegiatan pengawasan dapat terlaksana berkat dukungan dari semua pihak yaitu kepala sekolah, tutor, dan orang tua peserta didik. 


\section{PEMBAHASAN}

\section{Pihak-pihak yang Berperan dalam Implementasi Pendidikan Karakter di Sekolah Dolan Vila Bukit Tidar Malang}

Pendidikan karakter adalah pendidikan yang mempunyai tujuan untuk membentuk peserta didik agar mempunyai perilaku dan karakter yang lebih baik sesuai dengan nilai-nilai karakter dan dapat diterapkan dalam kehidupan sehari-hari, dan pendidikan karakter untuk peserta didik merupakan faktor penting yang harus diterapkan pada setiap individu agar setiap individu dapat memiliki sifat, kepribadian yang baik. Agar pendidikan karakter bisa berjalan dengan baik, dalam proses pendidikan karakter memerlukan peran berbagai pihak agar proses pendidikan karakter dapat berjalan seimbang. Selanjutnya, agar pendidikan karakter dapat berjalan dengan baik, dalam proses pendidikan karakter memerlukan peran berbagai pihak agar proses pendidikan dapat berjalan seimbang. Peran merupakan perilaku seseorang yang melaksanakan tugas atau kewajibannya dalam suatu sistem atau organisasi. Jika seseorang menjalankan tugasnya atau kewajiban yang dimilikinya maka mereka sedang menjalankan peran. Dari segi perannya pendidikan karakter dapat dimulai dari keluarga yang sangat berperan dalam proses pembentukan karakter anak.

Keluarga merupakan tempat pertama di mana seseorang sejak usia dini belajar apa yang baik dan mana yang buruk, benar atau salah. Berdasarkan hasil temuan penelitian ini, peran orangtua terhadap jalannya pendidikan karakter untuk anaknya di Sekolah Dolan ini adalah menempatkan tugas dan kewajiban sebagai orangtua; selalu memotivasi anak; menyiapkan diri menjadi model atau panutan yang baik; dan langsung terlibat dalam belajar anak. Hal tersebut didukung oleh teori Amirulloh (2015:74) bahwa peran keluarga dalam pendidikan karakter dapat ditempuh melalui cara-cara pengajaran, pemotivasian, peneladanan, pembiasaan, dan penguatan aturan.

Kepala Sekolah Dolan meskipun tidak terlibat langsung dengan proses pembelajaran kepada peserta didik, Bapak Lukman Hakim selalu mendukung keefektifan pendidikan karakter dengan cara mengkoordinasikan semua guru-guru di sekolah, Bapak Lukman Hakim juga sering terlihat akrab dan selalu memberikan arahan serta nasihat pada peserta didik di tengah waktu istirahat. Hal tersebut sesuai dengan teori yang dijelaskan oleh Gunawan (2012:178) bahwa "kepala sekolah memiliki kontribusi yang sangat penting dalam menyukseskan implementasi pendidikan karakter di sekolah, terutama dalam menggerakkan, mengkoordinasi, dan mengharmonisasikan semua sumberdaya pendidikan yang tersedia".

Pendidik berperan sebagai sumber belajar siswa dan terlibat langsung dalam proses pembelajaran, yaitu dengan melakukan hubungan langsung dengan peserta didik dalam mendiskusikan materi pembelajaran selain itu di Sekolah Dolan tutor berperan sebagai contoh tauladan peserta didik dan sebagai motivator peserta didik supaya peserta didik selalu semangat dalam belajar, sebagai pendidik tutor di Sekolah Dolan juga menunjukkan sikap-sikap yang terpuji dan selalu memberikan teladan untuk peserta didik. Hal didikung dengan teori yang dikemukakan oleh Zubaedi (2011:162) yaitu Para pendididik dan guru dalam konteks pendidikan karakter dapat menjadikan lima peran. Pertama, konservator (pemelihara) sistem nilai yang merupakan sumber norma kedewasaan;kedua, innovator (pengembang) sistem nilai ilmu pengetahuan; ketiga, transmit (penerus) sistem-sistem nilai ini kepada peserta didik;keempat, transformator (penerjemah) sistem nilai ini kepada siswa dengan penjelmaan dalam pribadinya dan perilakunya dalam proses interaksi dengan sasaran didik; dan kelima, organisator (penyelenggara) terciptanya proses pendidikan yang dapat dipertanggungjawabkan, baik secara formal maupun secara moral.

\section{Strategi Penerapan Nilai Karakter di Sekolah Dolan Vila Bukit Tidar Malang}

Sekolah Dolan merupakan sekolah nonformal yang menerapkan pendidikan karakter. Pelaksanaan pendidikan karakter untuk anak diharapkan dapat menjadi fondasi moral bangsa Indonesia. Pelaksanaan pendidikan karakter adalah kegiatan merealisasikan suatu kegiatan yang berkaitan dengan semua sasaran yang telah direncanakan oleh sekolah. Pelaksanaan pendidikan karakter di sekolah lebih berhubungan dengan penanaman nilai-nilai dan kepribadian yang baik pada diri peserta didik. 
Strategi penerapan nilai-nilai karakter diberikan melalui pengintegrasian nilai-nilai karakter dalam proses belajar mengajar berlangsung di dalam maupun di luar kelas, dimana dalam kegiatan pembelajaran guru selalu menanamkan sikap saling menghormati dalam perbedaan, dengan berdoa sesuai dengan kepercayaan masing-masing, mendorong siswa untuk menentukan agenda tujuan pembelajaran hari itu secara bersama-sama, guru selalu menyelipkan pesan kepada siswa yang berisi nasihat moral. Selanjutnya strategi penerapan nilai-nilai karakter melalui budayasekolah dan kegiatan pembiasaan merupakan proses pembentukan tingkah laku yang relatif menetap melalui proses pembelajaran yang berulangulang, karena pembiasaan merupakan bagian dari pendidikan. Kegiatan pembiasaan yang dilaksanakan di Sekolah Dolan Vila Bukit Tidar Malang adalah melalui kegiatan spontan, kegiatan rutin, kegiatan keteladanan, pengkondisian sekolah, dan kegiatan outbond. Pernyataan tersebut didukung dengan teori (Gunawan,2012) yang menyatakan bahwa strategi pelaksanaan pendidikan karakter dapat dilakukan melalui kegiatan pengembangan budaya sekolah yang dilakukan melalui kegiatan rutin, keteladanan, dan pengkondisian sekolah.

\section{Faktor Pendukung dalam Implementasi Pendidikan Karakter di Sekolah Dolan Vila Bukit Tidar Malang}

Keberhasilan pendidikan karakter perlu memperhatikan faktor yang dapat mendukung kesuksessan pendidikan karakter. Faktor pendukung keberhasilan pendidikan karakter di Sekolah Dolan yaitu adanya keinginan yang kuat untuk mendidik siswa agar memiliki karakter yang baik, melakukan kerjasama dengan tutor dan orang tua peserta didik dalam melaksanakan pendidikan karakter untuk siswa, rutin mengadakan rapat koordinasi tiap satu bulan sekali dengan tutor. Tujuan dari rapat koordinasi tersebut adalah memecahkan masalah secara bersama jika mengalami hambatan dalam pendidikan karakter, selanjutnya adanya sarana dan prasarana di sekolah menjadi faktor pendukung implementasi pendidikan karakter di sekolah.

Hal di atas sesuai dengan hasil penelitian yang ditemmukan Anggraini (2017: 155) faktor pendukung implementasi pendidikan karakter sebagai berikut: (a) mayoritas guru berusaha melaksanakan budaya sekolah; (b) mayoritas siswa semangat dan antusias; (c) mayoritas orang tua mendukung, dengan membantu pihak sekolah; dan (d) sarana dan prasarana sudah mendukung misalnya lapangan, perlengkapan altletik.

\section{Faktor Penghambat dalam Implementasi Pendidikan Karakter di Sekolah Dolan Vila Bukit Tidar Malang}

Setiap proses pendidikan karakter baik dalam kegiatan belajar mengajar atau kegiatan di luar kegiatan belajar mengajar tidak lepas dari faktor penghambat. Faktor penghambat dari pelaksanaan pendidikan karakter di Sekolah Dolan adalah kurangnya kesadaran dari peserta didik untuk menerapkan nilai-nilai karakter, dan keberagaman karakteristik peserta didik mengakibatkan tutor sulit mengkondisikan peserta didik. Hal di atas didukung dengan teori yang dikemukakan oleh Hidayat (2012: 15) "hambatan dalam pelaksanaan pendidikan yang paling kuat pada aspek personal internal adalah rendahnya penguasaan spiritual karakter pendidik dan tenaga kependidikan".

Adanya Hambatan dalam implementasi pendidikan karakter Sekolah Dolan mengupayakan untuk menanggulangi hambatan-hambatan dalam pelaksanaan pendidikan karakter. Upaya pemecahan hambatan tersebut yaitu kepala sekolah selalu mengadakan rapat koordinasi yang berfungsi sebagai sarana evaluasi terhadap kendala dalam proses pendidikan karakter untuk peserta didik, selain itu para tutor di Sekolah Dolan selalu memberikan teladan dan contoh-contoh yang positif untuk peserta didik agar terbiasa menanamkan nilai-nilai karakter dalam kehidupan sehari-hari, hal tersebut didukung dengan adanya teori yang dikemukakan oleh Furqon (dalam Wibowo, 2012) bahwa "seorang guru harus menguasai beberapa faktor mulia, agar bisa berhasil menginternalisasikan pendidikan karakter terhadap anak didik". 


\section{Bentuk Pengawasan Pendidikan Karakter di Sekolah Dolan Vila Bukit Tidar Malang}

Pengawasan merupakan proses memantau untuk memperkecil adanya penyimpangan-penyimpangan dari tujuan yang telah dirancang dengan membandingkan kegiatan nyata dengan standar yang telah ditetapkan sebelumnya. Pengawasan dan evaluasi adalah aktivitas yang keduanya memiliki tujuan yang sama yaitu mengawasi keberhasilan program. Proses pengawasan pendidikan karakter di Sekolah Dolan Vila Bukit Tidar Malang yaitu melibatkan seluruh anggota Sekolah Dolan. Jadi kepala sekolah, tutor dan orangtua peserta didik turut andil dalam pengawasan pendidikan karakter peserta didik. Selain itu pengawasan di Sekolah Dolan juga dilakukan secara langsung pada keseharian peserta didik di sekolah yaitu pada saat kegiatan belajar mengajar, pada saat istirahat dan mengawasi peserta didik saat sebelum pulang, hal ini dilakukan agar menghindari penyimpangan pada diri peserta didik. Selanjutnya untuk melakukan pengawasan Sekolah Dolan melakukan rapat tentang perkembangan pendidikan karakter peserta didik, dalam rapat ini berkoordinasi mengenai hambatan yang dihadapi guru pada saat pembelajaran ataupun permasalahan yang ada pada diri peserta didik yang harus pecahkan.

Pengawasan melalui evaluasi pencapaian perkembangan pendidikan karakter pada peserta didik menggunakan raport, dengan demikian orangtua mengetahui perkembangan peserta didik dan melakukan tindakan yang cepat apabila terdapat penyimpangan pada putra putrinya. Hal tersebut sama dengan hasil penelitian yang dilakukan oleh Sobri (2015: 21) bahwa "evaluasi kegiatan dilakukan dengan cara melaporkan secara lisan dan tertulis kegiatan apa yang dilaksanakan". Kegiatan evaluasi dilaksanakan pada waktu rapat yang diikuti seluruh tutor, kecuali kegiatan semesteran dan tahunan yang diikuti oleh yayasan bidang program sekolah.

Langkah lain yang dilakukan dalam melakukan pengawasan terhadap perkembangan pendidikan karakter peserta didik yaitu dengan pengisian buku jurnal, yang bertujuan untuk melihat perkembangan pembelajaran peserta didik. Hal tersebut didukung dengan teori yang dikemukakan oleh Kurniadin dan Machali (2012:131) yang berpendapat bahwa pengawasan adalah "suatu proses pengukuran dan pengamatan suatu kegiatan operasional dan hasil yang dicapai dibandingkan dengan standar yang telah ditentukan sebelumnya yang terdapat dalam rencana". Sebagaimana hal tersebut dapat disimpulkan bahwa proses pengawasan pendidikan karakter adalah upaya untuk melihat atau mengukur tingkat ketercapaian pendidikan karakter tersebut dengan perencanaan yang telah rancang sebelumnya.

\section{KESIMPULAN}

Pihak-pihak yang terlibat dalam jalannya pendidikan karakter di Sekolah Dolan Vila Bukit Tidar Malang adalah Kepala sekolah, Tutor dan tenaga kependidikan, dan orangtua peserta didik berperan dalam memperlancar jalannya pendidikan karakter di sekolah. Strategi pengintegrasian nilai-nilai karakter di Sekolah Dolan dilakukan melalui berbagai kegiatan yaitu kegiatan belajar mengajar, kegiatan pembiasaan, budaya sekolah, dan kegiatan outbond. Adapun faktor pendukung pendidikan karakter di Sekolah Dolan Vila Bukit Tidar Malang adalah adanya keinginan yang kuat untuk mendidik siswa agar memiliki budi pekerti yang baik; melakukan kerjasama dengan tutor dan orang tua peserta didik dalam melaksanakan pendidikan karakter untuk siswa; rutin mengadakan rapat koordinasi setiap satu bulan sekali dengan tutor yang bertujuan untuk berkomunikasi dan dapat memecahkan masalah secara bersama jika menemukan masalah yang dihadapi khususnya dalam pendidikan siswa; dan adanya fasilitas-fasilitas pendukung di sekolah. Sedangkan faktor penghambat pelaksanaan pendidikan karakter adalah kurangnya kesadaran dari siswa untuk menanamkan nilai-nilai karakter, dan keberagaman karakteristik peserta didik menjadikan tutor susah untuk mengkondisikan. Pengawasan pendidikan karakter di Sekolah Dolan Vila Bukit Tidar Malang dilakukan secara langsung pada proses kegiatan pembelajaran berlangsung, pada saat istirahat dan mengawasi anak saat sebelum pulang, selain itu sekolah juga melakukan rapat tentang perkembangan pendidikan karakter peserta didik jangka waktu dilakukan pada satu bulan sekali, dan Pengawasan melalui Raport yang dilaporkan kepada orang tua setiap akhir semester. 


\section{DAFTAR RUJUKAN}

Amirulloh. 2015. Teori Pendidikan Karater Remaja dalam Keluarga. Bandung:Alfabeta.

Anggraini, M.S.A. 2017. Implementasi Pendidikan Karakter Melalui Budaya Sekolah Di SDN Kota Gede 3 Yogyakarta Tahun Ajaran 2016/2017. Jurnal Pendidikan Ke-SD-an, (Online), 3(3):151-158, (http://download. portalgaruda.org $/$ article.php?article $=519739 \& \mathrm{val}=10636 \&$ title=IMPLEMENTASI $\% 20$ PENDIDIKAN $\% 20$

KARAKTER\%20MELALUI\%20BUDAYA\%20SEKOLAH\%20DI\%20SD\%20N\%20KOTAGEDE\%20 3\%20YOGYAKARTA\%20TAHUN\%20AJARAN\%202016/2017), diakses 12 Maret 2017.

Bafadal, I. 2016. Penilaian Kinerja Kepala Sekolah Sebagai Pemimpin Pembelajaran Dalam Rangka Peningkatan Akuntabilitas Sekolah. Manajemen Pendidikan, (Online), 25 (1): 1-9, (http://ap.fip.um.ac.id/?page_id=384), diakses 23 Oktober 2017.

Gunawan, H. 2012. Pendidikan Karakter:Konsep dan Implementasi. Bandung:Alfabeta.

Hidayat, A.S. 2012. Manajemen Sekolah Berbasis Karakter. Jurnal Inovasi dan Kewirausahaan, (Online), 1 (1): 8-22, (http://www.jurnal.uii.ac.id/ajie/article/download/2580/2364). diakses 6 Februari 2018.

Kemdiknas. 2010. Pengembangan Pendidikan Budaya dan Karakter Bangsa. Jakarta: Badan Penelitian dan Pengembangan Pusat Kurikulum.

Kurniadin, D. \& Machali, I. 2012. Manajemen Pendidikan:Konsep \& Prinsip Pengelolaan Pendidikan. Jogjakarta: Ar-Ruzz Media.

Marzuki. 2015. Pendidikan Karakter Islam. Jakarta:Amzah.

Moelong, L. J. 2010. Metodologi Penelitian Kualitatif. Bandung:PT. Remaja Rosdakarya.

Muslich, M. 2011. Pendidikan Karakter Menjawab Tantangan Kritis Multidimensional. Jakarta: PT Bumi Aksara.

Salim, A. 2015. Manajemen Pendidikan Karakter di Madrasah (Sebagai Konsep dan Penerapannya). Jurnal Tarbawi, (Online), 1 (2) : 1-16 (http://jurnal.uinbanten.ac.id/index.php/tarbawi/article/download/256/253/). diakses 17 Oktober 2017.

Sobri, A.Y. 2015. Menumbuhkan Nilai Karakter Siswa Di Sekolah. Manajemen Pendidikan, (Online), 23 (1): $34-$ 47, (http://journal2.um.ac.id/index.php/sd/article/view/1347), diakses 29 September 2017.

Sobri, A.Y. 2010. Manajemen Pendidikan Karakter Berbasis Religi di Sekolah Dasar. Manajemen Pendidikan, (Online), 24 (1): 18-21, (http://ap.fip.um.ac.id/wp-content/uploads/2015/10/1-ahmad-yusuf-sobri.pdf), diakses 6 April 2018.

Sutama \& Rahayu, S. M. 2015. Pengelolaan Sarana dan Prasarana Pendidikan Sekolah Menengah Pertama, (Online), 27(2): 123-129, (http://download.portalgaruda.org/article.php?article=450022\&val=8121\&title $=$ Pengelolaan $\% 20$ Sarana $\% 20$ dan $\% 20$ Prasarana $\% 20$ Pendidikan\%20Sekolah\%20Menengah\%20Pertama), diakses 3 Mei 2018.

Ulfatin, N. 2015.Metode Penelitian Kualitatif di Bidang Pendidikan:Teori dan Aplikasinya. Malang: FIP UM.

Wibowo, A. 2012. Pendidikan Karakter. Yogyakarta: Putaka Pelajar.

Zubaedi. 2011. Desain Pendidikan Karakter. Jakarta: Kencana Prenada Media Group. 